\author{
Research Article \\ www.ijrap.net
}

\title{
ANATOMICAL STUDIES ON THE SEEDS OF ALTERNANTHERA SESSILIS LINN.
}

\author{
B. Akila ${ }^{1}$, K. Manickavasakam ${ }^{2}$
}

${ }^{1} \mathrm{Ph}$. D Scholar, Department of Maruthuvam, National Institute of Siddha, Chennai, Tamil Nadu, India

${ }^{2}$ Director, National Institute of Siddha, Chennai, Tamil Nadu, India

Received on: 10/04/14 Revised on: 05/05/14 Accepted on: 20/05/14

\author{
*Corresponding author \\ Dr. B. Akila, Ph. D Scholar, Department of Maruthuvam, National Institute of Siddha Chennai, Tamil Nadu, India \\ E-mail: drakila10@gmail.com \\ DOI: $10.7897 / 2277-4343.05368$
}

\begin{abstract}
Alternanthera sessilis Linn belongs to the family Amaranthaceae. It is an annual or a perennial prostate herb with several spreading branches bearing short petioles, simple leaves and small white flowers. The branches are raised from the root and are up to $50 \mathrm{~cm}$ long. The seed is used in Siddha system of medicine. So far no Anatomical characters have been reported on the seeds of Alternanthera sessilis Linn. The aim of this study was to evaluate the Macroscopic and microscopic characters of the fresh seed samples of Alternanthera sessilis Linn. The seed samples were mounted on FAA solution. Sections were taken in rotary microtome, stained with toluidine blue characters, histochemical tests were observed. The seed is $400 \mu \mathrm{m}$ long and $250 \mu \mathrm{m}$ wide, Seed coat ( Testa) is $10 \mu \mathrm{m}$ thick and hard. Both outer and inner seed coats are sclerotic with prominent appendages on the outer surface of the seed coat. Endosperm is large, thin walled and polyhedral. Anatomical characters reported on the seeds of Alternanthera sessilis Linn can be used as a diagnostic tool for the botanical identity and authentication of the correct plant material.
\end{abstract}

Keywords: Alternanthera sessilis Linn, Anatomical, Macroscopic, Microscopic, Seed, Siddha.

\section{INTRODUCTION}

Alternanthera sessilis Linn belongs to the family Amaranthaceae. It is an annual or a perennial prostate herb with several spreading branches bearing short petioles, simple leaves and small white flowers ${ }^{1}$. The branches are raised from the root and reaches up to $50 \mathrm{~cm}$ long $^{2}$. Vernacular names are Ponnonkanni keerai (Siddha/Tamil), Matsyaakshi (Ayurvedic), Machhechhi (Unani) and Gudari Saag (Folk) ${ }^{3}$. Common name is sessile joy weed, used as traditional medicine in India, China, Sri Lanka and Taiwan ${ }^{4}$. Siddha mentioned Alternanthera sessilis as a Kaya Kalpa drug ${ }^{5}$. Shoot with other ingredients is used to restore virility ${ }^{6}$. Alternanthera is enriched with Vitamins, flavonoids, glycosides, saponins and other secondary metabolites ${ }^{7}$. Seed oil contains a moderate source of Ricinoleic, Myristic, Palmitic, Stearic, Oleic and Linoleic acids ${ }^{8}$. The seed of Alternanthera sessilis Linn is used in Siddha system of medicine as one of the ingredient in the herbal mineral formulation Chandrakanthi choornam indicated in Nocturnal emission, Oligospermia, Urinary disease, Vaginal disease, Venereal disease and All biliousness? According to World Health Organization the macroscopic and microscopic determination of the plant is the first step towards establishing its identity and purity ${ }^{10}$. Proper identification and authentication based on established scientific criteria are of utmost importance ${ }^{11}$. No anatomical characters are reported on the seed of Alternanthera sessilis Linn and hence the present study was done to evaluate the macroscopic and microscopic characters of the fresh seed samples.

\section{MATERIALS AND METHODS Plant Material}

For the proposed study fresh seed samples were collected from the Herbal garden, National Institute of Siddha, Chennai, India. It was identified, authenticated and a voucher specimen (NIS/MB/59/2012) was deposited in the Department of Medicinal Botany, National Institute of Siddha, Chennai, India. Anatomical analysis was done in Plant Anatomy Research Centre, Chennai, India.

\section{Anatomical analysis of the Seed \\ Macroscopic and microscopic analysis}

The seeds were fixed in FAA (Formalin $-5 \mathrm{ml}+$ acetic acid $-5 \mathrm{ml}+70 \%$ Ethyl alcohol $-90 \mathrm{ml})$. After $24 \mathrm{~h}$ of fixing, the specimens were dehydrated with a graded series of tertiary- Butyl alcohol ${ }^{12}$. Infiltration of the specimens was carried by gradual addition of paraffin wax (melting point $58-60{ }^{0} \mathrm{C}$ ) until TBA solution attained super saturation. The specimens were cast into paraffin blocks.

\section{Sectioning}

The paraffin embedded specimens were sectioned with the help of Rotary Microtome. The thickness of the sections was $10-12 \mu \mathrm{m}$. De waxing of the sections was by customary procedure $^{13}$. The sections were stained with toluidine blue since it is a polychromatic $\operatorname{stain}^{14}$. The staining results were remarkably good and some cytochemical reactions were also obtained. The dye rendered pink colour to the cellulose walls, blue to the lignified cells, dark green to suberin, violet to the mucilage, blue to the protein bodies etc. Wherever necessary, sections were also stained with safranin and Fast-green and IKI (for Starch)

\section{Photomicrographs}

Microscopic descriptions of tissues are supplemented with micrographs, wherever necessary. Photographs of different magnifications were taken with Nikon lab photo 2 microscopic Unit. For normal observations bright field was used. For the study of crystals, starch grains and lignified cells, polarized light was employed. Since these 
structures have birefringent property, under polarized light they appear bright against a dark background. Magnifications of the figures are indicated by the scalebars. Descriptive terms of the anatomical features are as given in the standard anatomy books ${ }^{15}$.

\section{RESULTS AND DISCUSSION}

Macroscopical characters of seed

The seeds are dark brown (Figure 3) with no odour, elliptical in shape with a broad blunt end and short conical opposite end (Figure 4). The seed is $400 \mu \mathrm{m}$ long and 250 $\mu \mathrm{m}$ wide.

\section{Microscopical characters of seed}

The seed-coat (Testa) is thick and hard. It is $10 \mu \mathrm{m}$ thick. It is uniformly thick all around the seed. The outer surface is uneven with irregular ridges. On the outer surface of the seed coat there are two or three prominent appendages or wings (Figure 8). The wings are $80 \mu \mathrm{m}$ long and $30 \mu \mathrm{m}$ thick. The wings are multicellular and thick walled. They are conical in shape. The seed coat consists of outer sclerotic epidermis or sclerotesta and inner seed coat which are also sclerotic. There are two or three layers of fibrous cells (Figure 7,8). The endosperm is large, thin walled and polyhedral in outline (Figure 5, 6).

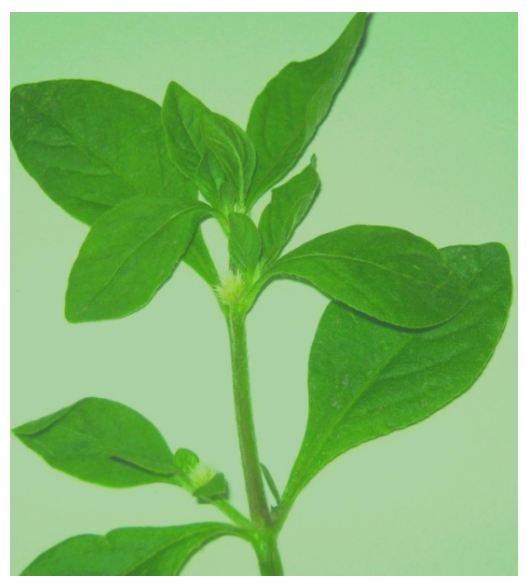

Figure 1: Plant image of Alternanthera sessilis
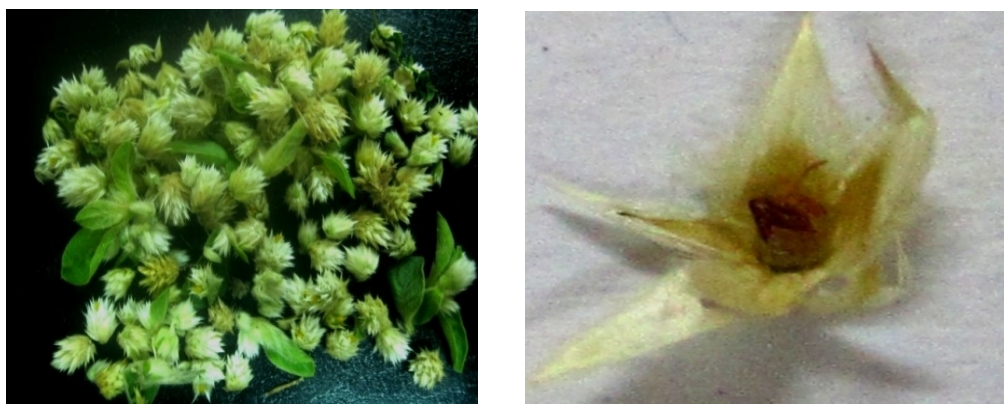

Figure 2: Flower with seed
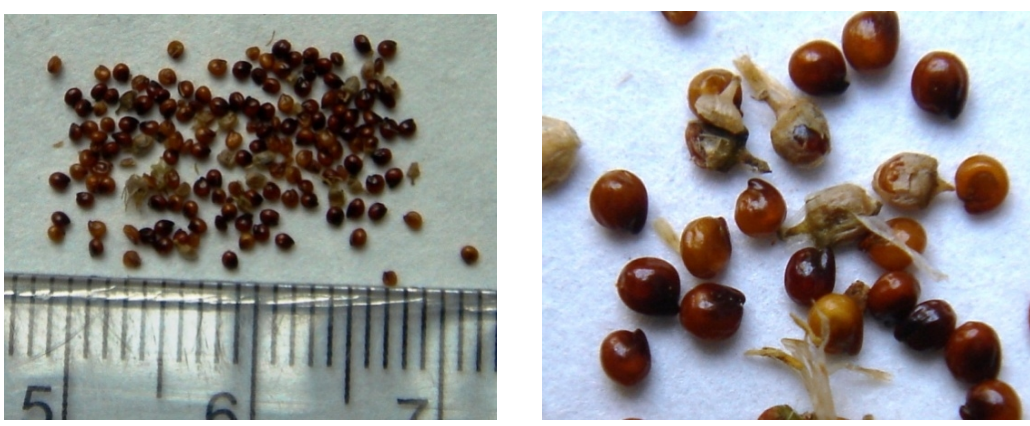

Figure 3: Seeds external feature 


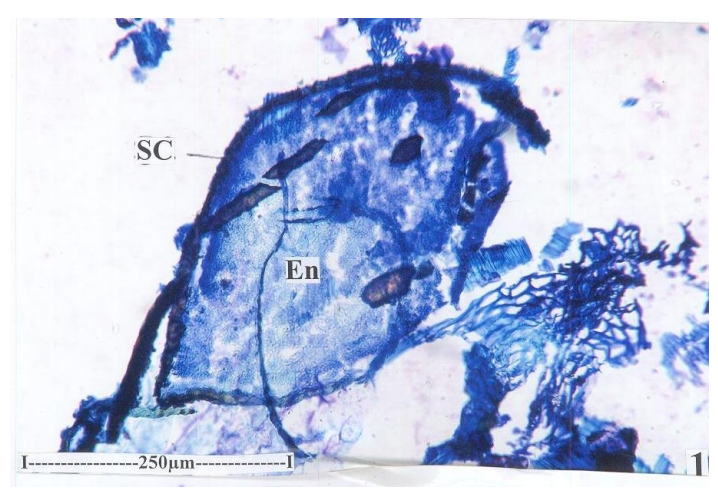

Figure 4: LS of seed - entire view $-16 x$

(En- Endosperm; Sc- Seed coat)

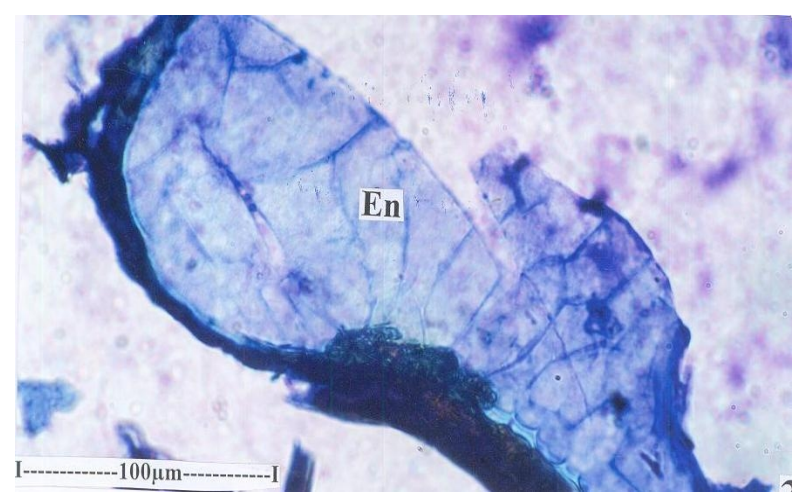

Figure 6: Cellular endosperm of the seed $-40 x$ (En- Endosperm)

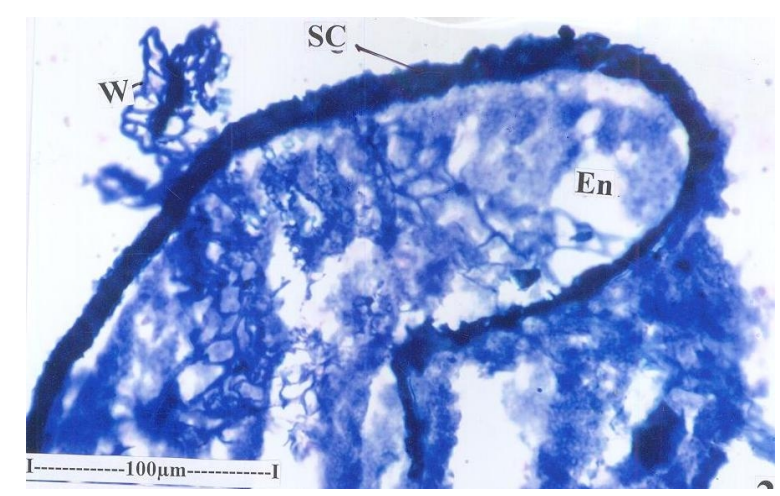

Figure 5: Seed coat with outer wing $-40 x$ (En- Endosperm; Sc- Seed coat)

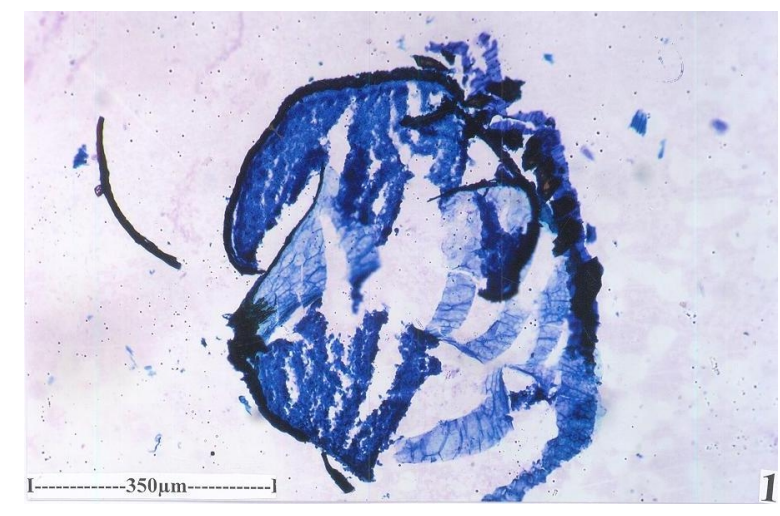

Figure 7: TS of seed $-10 x$

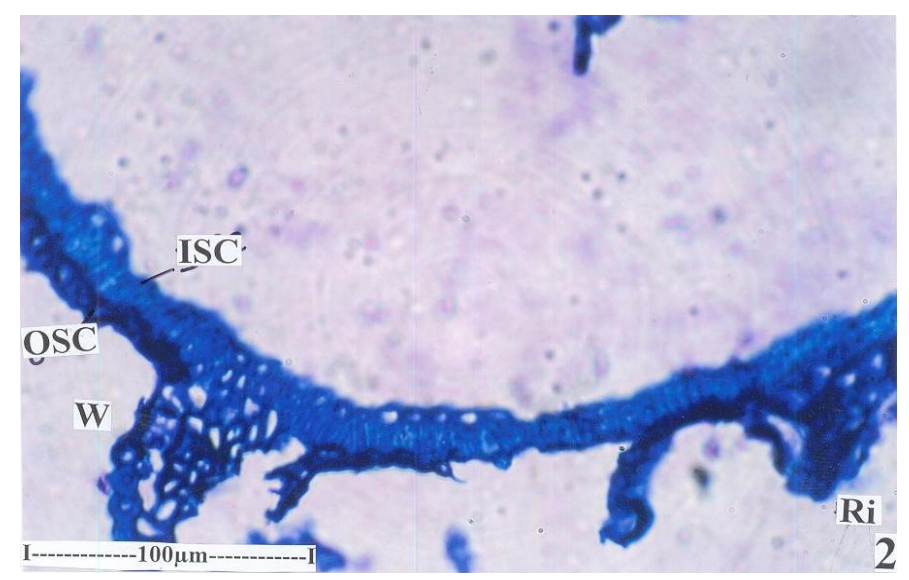

Figure 8: Seed coat enlarged showing sclerotic testa and outer outgrowing wing $-40 \mathrm{x}$ (ISC: Inner seed coat; OSC: outer seed coat; W: Wing)

\section{CONCLUSION}

Anatomical characters reported on the seeds of Alternanthera sessilis can be used as a diagnostic tool for the botanical identity and authentication of the correct plant material and to differentiate the drug from its allied species. The Macroscopical and microscopical characters established on the seed may be helpful in the development of standard pharmacopoeia literature for this material.

\section{ACKNOWLEDGEMENT}

Authors are thankful to Dr. D. Aravind, Assistant Professor, NIS for authentication and Dr. P. Jayaraman, Director, Plant Anatomy Research Centre, Chennai, India for technical suggestions. 


\section{B. Akila et al / Int. J. Res. Ayurveda Pharm. 5(3), May - Jun 2014}

\section{REFERENCES}

1. Subhashini T et al. Anti- Inflammatory Activity of Leaf Extracts of Alternanthera sessilis. Hygeia J D Med 2010; 2(1): 54-56.

2. Yadav et al. In vitro antioxidant and free radical scavenging activity of Alternanthera sessilis. International Journal of Pharma Sciences and Research 2011; 2(6): 1502-1506.

3. Khare CP. Indian Medicinal Plants- an iilustrated dictionary.Berlin/Heidelberg: Springer-Verlag; 2007. p. 39.

4. Surendra Kumar $\mathrm{M}$ et al. Screening of aqueous and ethanolic extracts of aerial parts of Alternanthera sessilis Linn. R. Br. ex.DC (Amaranthaceae) For Antidiabetic Activity. Journal of Pharmacy Research 2011; 4(5): 1528-1530.

5. Rajiv Gupta et al., Nootropic potential of Alternanthera sessilis and Clerodendrum infortunatum leaves on mice. Asian Pacific Journal of Tropical Disease 2012; 2(1): 465-470. http://dx.doi.org /10.1016/S2222-1808(12)60204-7

6. Asolkar LV, Kakkar KK, Chakre OJ. Second supplement to Glossary of Indian Medicinal Plants with Active principles. Part-I (A-K). New Delhi: $1^{\text {st }}$ ed. National Institute of Science Communcate and Information Resources (CSIR); 1992.

7. Hundiwale Jogendra $\mathrm{C}$ et al. A current update on phytopharmacology of the genus Alternanthera. Journal of Pharmacy Research 2012; 5(4): 1924-1929.

8. Hosamani Kallappa M, Ganjihal Savita S, Chavadi Dheeraj V. Alternanthera triandra seed oil: A moderate source of ricinoleic acid and its possible industrial utilization. Industrial Crops and
Products 2004; 19(2): 133-136. http://dx.doi.org/10.1016 /j.indcrop.2003.07.009

9. Vaidhiya Vithuvanmani Kanusamy Pillai. Sigicha Rathna Deepam ennum vaidhiya nool. Part-II. Chennai: B. Rathinanayakar and Sons; 2007. p. 168.

10. Bigoniya1 $\mathrm{P}$ et al. Pharmacognostical and physico-chemical standardization of Syzygium cumini and Azadirachta indica seed. Asian Pacific Journal of Tropical Biomedicine 2012; 290-295.

11. Mariappan et al. Pharmacognostical studies on Morinda tinctoria. roxb. Int J Pharm Pharm Sci 2012; 4(2): 636-638.

12. Sass JE. Elements of botanical Microtechnique. New York: $1^{\text {st }}$ ed Mc Graw Hill Book Co; 1940. p. 222.

13. Johansen DA. Plant Microtechnique. New York: $1^{\text {st }}$ ed. Mc Graw Hill Book Co; 1940. p. 523.

14. O Brien TP, Feder N, Mc Cull ME. Polychromatic staining of plant cell walls by toluidine blue-O. Protoplasma 1964; 59: 364-373. http://dx.doi.org/10.1007/BF01248568

15. Easu K. Anatomy of seed Plants. New York: John Wiley and sons; 1979. p. 550.

Cite this article as:

B. Akila, K. Manickavasakam. Anatomical studies on the seeds of Alternanthera sessilis Linn. Int. J. Res. Ayurveda Pharm. 2014;5(3):330333 http://dx.doi.org/10.7897/2277-4343.05368 